\title{
A SCANNING ELECTRON MICROSCOPY STUDY OF ROOT SURFACE SMEAR LAYER REMOVAL AFTER TOPICAL APPLICATION OF EDTA PLUS A DETERGENT
}

\author{
REMOÇÃO DE SMEAR LAYER DE SUPERFÍCIES RADICULARES COM APLICAÇÃO \\ TÓPICA DE EDTA E EDTA COM DETERGENTE. ANÁLISE EM MICROSCOPIA \\ ELETRÔNICA DE VARREDURA
}

José Eduardo Cezar SAMPAIO ${ }^{1}$, Flávia Pavan CAMPOS², Gibson Luiz PILATTI ${ }^{3}$, Letícia Helena THEODORO ${ }^{3}$, Fábio Renato Manzolli LEITE ${ }^{2}$

\begin{abstract}
1- PhD, Professor, Department of Diagnosis and Surgery, Discipline of Periodontology, Araraquara Dental School, State University of São Paulo (UNESP), Araraquara, SP, Brazil.

2- Graduate in Dentistry, Araraquara Dental School, State University of São Paulo (UNESP), Araraquara, SP, Brazil.

3- PhD, Division of Periodontics, Araraquara Dental School, State University of São Paulo (UNESP), Araraquara, SP, Brazil.

Corresponding address: Dr. José Eduardo Cezar Sampaio - Departamento de Diagnóstico e Cirurgia, Disciplina de Periodontia, UNESP - Faculdade de Odontologia de Araraquara - Rua Humaitá, 1.680 - Cep.: 14801-903 - Araraquara - SP - Brazil - Phone/Fax: (+55) 16 201-6369 - email: perio@foar.unesp.br (may include in the "send reprint requests" statement) - Financial support: CNPq - Conselho Nacional de Desenvolvimento Científico e Tecnológico
\end{abstract}

Received: June 23, 2004 - Modification: September 09, 2004 - Accepted: May 15, 2005

\begin{abstract}
$T_{\text {re }}$

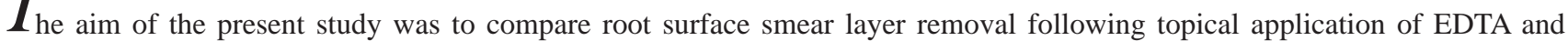
EDTA-T (Texapon). Extracted human teeth had their cementum removed and were mechanically scaled. A total of 220 root specimens were obtained and were randomly assigned to the following groups: I-saline solution (control), II-EDTA; III-EDTAT. Groups II and III specimens were assigned to different EDTA gel concentrations: 5\%, 10\%, 15\%, 20\% and 24\%. Smear layer removal score was assessed for each specimen by scanning electron microscopy. The results demonstrated that EDTA and EDTA-T gel led to a higher root surface smear layer removal when compared to the control group. The 5\% EDTA gel also showed a higher smear layer removal than the $15 \%, 20 \%$ and $24 \%$ EDTA gels $(\mathrm{p}<0.05)$. No difference could be found between the different concentrations of EDTA-T gels tested ( $>>0.05)$. EDTA gels had statistically significantly lower smear layer scores than the EDTA-T gels for the 5\% and 10\% concentrations. The results suggested that topical application of EDTA or EDTA$\mathrm{T}$ gel led to significant smear layer removal of the mechanically treated root surfaces. The addition of a detergent to the EDTA gel formula did not improve smear layer removal of the root surface.

Uniterms: Periodontal disease; EDTA etching; Smear layer; Root planing.
\end{abstract}

\footnotetext{
RESUMO

Q

objetivo do presente estudo foi comparar, através de microscopia eletrônica de varredura, a remoção de smear layer de superfícies radiculares após aplicação tópica de gel de EDTA com gel de EDTA-T (Texapon). Foram utilizados dentes humanos que foram submetidos a remoção de cemento radicular e raspagem. As amostras dos dentes foram divididas em 3 grupos: Grupo I- (controle) (n=20); Grupo II- gel de EDTA (pH 7,0) nas concentrações de 5\%,10\%,15\%,20\% e 24\% (n=100); Grupo II gel de EDTA-T $(\mathrm{pH} 7,0)$ nas concentrações acima descritas $(\mathrm{n}=100)$. As fotomicrografias foram avaliadas através de um índice e os dados foram estatisticamente analisados. Ambos os tratamentos com EDTA foram efetivos na remoção de smear layer quando comparados ao grupo controle. O gel de EDTA a 5\% demonstrou maior capacidade na remoção de smear layer quando comparado com as concentrações de $15 \%, 20 \%$ e $24 \%$ (p<0,05). Não houve diferença entre as concentrações de géis de EDTA$\mathrm{T}(\mathrm{p}>0,05)$. Os géis de EDTA foram mais efetivos que o EDTA-T nas concentrações de 5 e $10 \%$. Os resultados sugerem que a aplicação tópica de EDTA ou EDTA-T é efetiva na remoção de smear layer, principamente em baixas concentrações e a adição do Texapon não promove vantagens neste tratamento.

Unitermos: Doença periodontal; EDTA, condicionamento; Smear layer; Raspagem.
} 


\section{INTRODUCTION}

One of the goals of periodontal therapy is to obtain predictable regeneration of the periodontium in areas previously affected by periodontal disease ${ }^{14,24}$. The key role of the diseased root surface in the regenerative process has been previously described ${ }^{22}$ and the acid conditioning of the root surface after scaling and root planing has been introduced as a promising procedure for endotoxins and smear layer removal ${ }^{21,23}$.

In several in vitro studies different agents, such as citric acid $^{16}$, ethylenediaminetetraacetic acid ${ }^{4}$ (EDTA) and tetracycline hydrocloride ${ }^{25}$, have been employed successfully for smear layer removal. However, clinical studies have not demonstrated significant clinical differences ${ }^{9,10}$. This smear layer removal and dentinal tubules exposure have been described as factors that may favor clot stabilization in the earliest stages of periodontal healing event by increasing blood cells and fibrin adhesion to the root surface ${ }^{3}$, or even improving the retention of some substances such as enamel matrix on the root surface which would act as growth factors in the periodontal healing process $^{13}$.

Regarding the cervical dentine hypersensitivity therapy, smear layer removal could lead to a higher permeability of the desensitizing chemical agents through the dentinal tubules, since it has not been possible to demonstrate their diffusion through the dentinal tubules in the presence of smear layer ${ }^{15,19}$. The use of decalcifying agents at neutral $\mathrm{pH}$, such as EDTA, has been suggested because they not only preserve the vitality of the remaining periodontal cells close to the root surface, but they also remove calcium ions of the collagen dentin matrix more selectively than low-pH etching agents ${ }^{10}$. The use of etching agents in gel form may provide a better control of the area that must be conditioned, once the liquid form may drop on the adjacent tissue ${ }^{10}$.

Root surfaces treated with different detergents have shown a partially demineralized aspect, with open dentinal tubules and exposed collagen fibers ${ }^{20}$. Although detergents used alone seem to remove bacteria and toxins of the root surface, they have not led to a selective removal of hydroxyapatite and have not exposed collagen fibers of the cementum or dentin extracellular matrix ${ }^{18}$.

The aim of the present study was to compare by scanning electron microscopy (SEM) the smear layer removal following topical application of EDTA gel and EDTA gel with Texapon detergent (EDTA-T), added to EDTA in order to decrease the surface tension and to facilitate the spreading over the root surface. Also, the influence of concentration and application time of these substances on smear layer removal was evaluated.

\section{MATERIALAND METHODS}

\section{Teeth Preparation}

This study was approved by Araraquara Dental School ethics committee. One hundred and ten premolars and third molars indicated for extraction due to orthodontic reasons were used in this research. After extraction teeth were stored in a recipient with saline solution to avoid dehydration.

Using a high speed cylindrical bur under copious irrigation, two parallel retention grooves were made on the buccal and lingual root surfaces of each tooth: one at the cementum/enamel junction and the other one $4 \mathrm{~mm}$ apically to the first.

After that, the cementum between the two grooves was removed with the same cylindrical bur cited before. Immediately, scaling and root planing procedures were made by means of a Gracey 5-6 curette* leading to smear layer formation which was attempted to be remove with the EDTA and EDTA-T gels.

Samples were obtained using a diamond $\operatorname{disc}^{\dagger}$. Roots were crosscut in the first groove separating this away of the crown. Then roots were cut lengthwise in mesiodistal direction until the second groove was reached apically where the sample was crosscut and separated in two samples of about $2 \mathrm{~mm}$ wide by $3 \mathrm{~mm}$ long. The next step was the storage of these specimens in a recipient with saline solution to avoid dehydration.

\section{Treatment Groups}

Specimens were randomly distributed according to the following treatment groups:

Group I: (control) Irrigation with saline solution.

Group II: EDTA gel (pH 7.0) was applied in the following concentrations: $5 \%, 10 \%, 15 \%, 20 \%$ and $24 \%$.

Group III: Application of EDTA-T gel (pH 7.0) in the concentrations of 5\%, 10\%, 15\%, 20\% and 24\%.

In groups II and III, EDTA and EDTA-T gels were applied with a cotton pellet, which was replaced every 30 seconds. For each concentration gels were applied for 1, 2 or 3 minutes, followed by irrigation with $10 \mathrm{~mL}$ of saline solution, or they received a 1-minute-application for 3 times, with $10 \mathrm{~mL}$ saline solution irrigation between each 1-minute gel application.

For each application time five samples were used, in a total of 20 samples for each concentration of EDTA and EDTA-T. This way, one hundred samples were used in groups II and III, and twenty samples were used in group I (control), in a total of 220 samples.

\section{Sample Preparation for SEM}

After treatment of the root surfaces, samples were fixed in $2.5 \%$ glutaraldehyde in phosphate buffer ( $\mathrm{pH} 7.3$ ) for 24 hours and washed three times with phosphate buffer. 
Specimens were then dehydrated in a graded series of aqueous-ethanol solutions (50\%, 70\%, 85\%, 95\% and 100\% ethanol) for 10 minutes each. Afterward the samples were dried overnight in a dehydration jar, mounted on SEM stubs and sputter-coated with gold.

\section{SEM Examination}

Photomicrographs were obtained with a 3500 times magnification from a random area for each specimen, using a SEM ${ }^{\ddagger}$. Three previously calibrated and trained examiners independently evaluated the photomicrographs, in order to determine smear layer removal of the root surface using the following scores:

Score 1: Root surface without smear layer with the dentinal tubules completely open without evidence of smear layer in the dentinal tubules.

Score 2: Root surface without smear layer with the dentinal tubules completely open, but with some evidence of smear layer in the dentinal tubules entrance.

Score 3: Root surface without smear layer with the dentinal tubules partially open.

Score 4: Root surface covered by a uniform smear layer, with evidence of dentinal tubules opening.

Score 5: Root surface covered by a uniform smear layer without evidence of dentinal tubules opening.

Score 6: Root surface covered by an irregular smear layer, with the presence of grooves and/or scattered debris.

\section{Statistical Analysis}

Smear layer removal scores were independently analyzed considering group (control, EDTA and EDTA with Texapon), concentration and application time as independent variables. The non-parametric Kruskal Wallis test was used to compare the mean rank for each group, concentration, as well as for

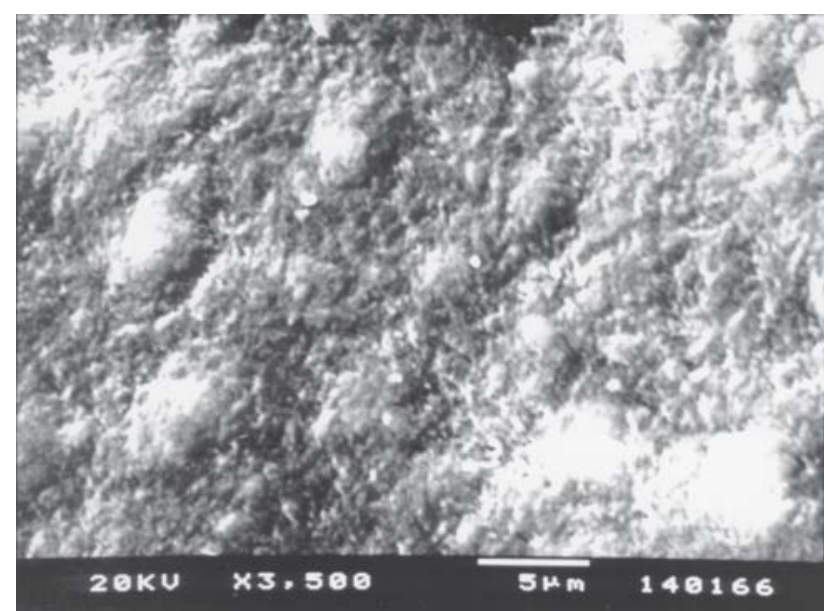

FIGURE 1- SEM of a control group specimen showing a uniform smear layer (score 6). (3500x magnification; bar $=5 \mu \mathrm{m})$ each application time tested. If $\mathrm{p} \leq 0.05$, Dunn's Multiple Comparison test was applied to detect statistically significant differences between groups, concentrations and application times tested. The non-parametric Mann-Whitney test was used to compare smear layer removal scores between groups II (EDTA) and III (EDTA with Texapon) for each concentration tested $(p \leq 0.05)$. The statistical analyses were performed using a computer software ${ }^{\S}$.

\section{RESULTS}

\section{Group I (control)}

In five specimens the root surface was covered by a uniform smear layer without evidence of dentinal tubules opening (score 5). The other 15 specimens had a heavy smear layer with presence of grooves and scattered debris. Scratches caused by manual instrumentation were observed (Figure 1).

Group II (EDTA)

In 5\% EDTA group ten specimens had no smear layer with the dentinal tubules completely open without evidence of smear layer in the dentinal tubules entrance (score 1) (Figure 2) and eight specimens with the dentinal tubules completely open, but with some evidence of smear layer in the dentinal tubules entrance (score 2). One specimen had no smear layer with the dentinal tubules partially open (score 3) and only one specimen had the root surface covered by a uniform smear layer (score 4).

The 10\% EDTA group displayed 12 specimens with the dentinal tubules completely open, but with some evidence of smear layer in the dentinal tubules entrance (score 2) (Figure 3). In the 15\% EDTA group seven specimens showed the root surface without smear layer with the dentinal tubules partially open (score 3) and five specimens displayed root surface covered by a uniform smear layer, with evidence of

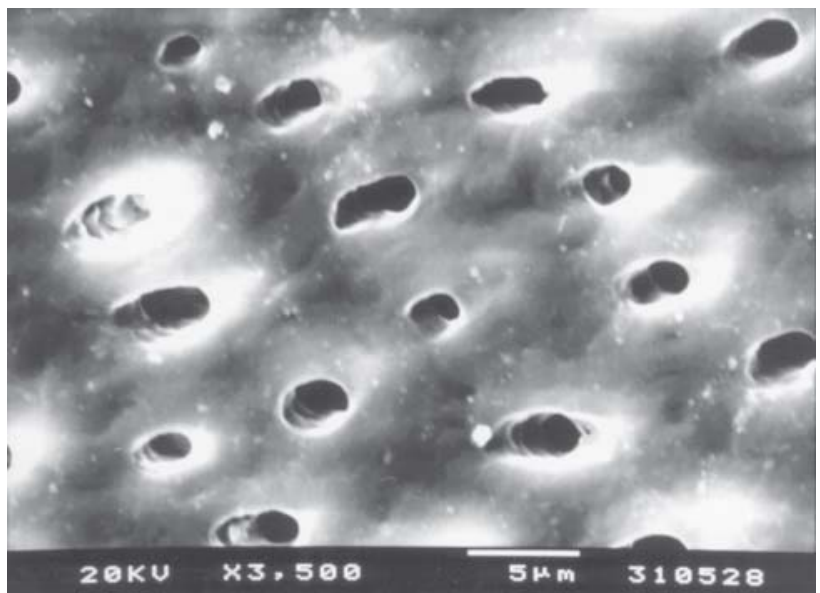

FIGURE 2- SEM of a 5\% EDTA group specimen showing a root surface without smear layer with dentinal tubules completely open (score 1$)$. (3500x magnification; bar $=5$ $\mu \mathrm{m})$
‡ JEOL JSM - T330A

$\S$ Graphpad Instat 3.05 
dentinal tubules opening and, on the other hand, five specimens had no smear layer with the dentinal tubules completely open, but with some evidence of smear layer in the dentinal tubules entrance. Seven specimens had no smear layer with the dentinal tubules partially open (score 3) and seven had smear layer with evidence of dentinal tubules opening (score 4) in 20\% EDTA group. Finally, in the 24\% EDTA group fourteen specimens had no smear layer (score 1, 2 or 3) and eleven had dentinal tubules partially open (score 3) (Figure 4).

Group III (EDTA-T)

The 5\% EDTA group displayed seven specimens with root surface covered by a uniform smear layer without evidence of dentinal tubules opening, ten specimens had no smear layer (score 1, 2 or 3) and only one specimen had no smear layer with the dentinal tubules completely open (score 1). In the 10\% EDTA-T group eleven specimens had no smear layer (score 2 or 3); in the 15\% EDTA-T group fourteen specimens had no smear layer (score 1, 2 or 3 ) and in the 20\% EDTA-T group sixteen specimens had no smear layer (score 1, 2 or 3). Finally, in the 24\% EDTA-T group fifteen specimens had no smear layer (score 2 or 3 ) (Figure 5).

\section{Data Analysis}

Considering concentration as an independent variable, the non-parametric Kruskall Wallis test showed that there was a statistically significant difference between the concentrations tested regarding smear layer scores $(p<0.0001)$. Dunn's Multiple Comparison test demonstrated that all the EDTA gels exhibited statistically significant lower smear layer scores when compared to the control group $(p<0.01)$. The 5\% EDTA gel also showed a higher smear layer removal than the 15\%, 20\% and 24\% EDTA gel $(\mathrm{p}<0.05)$. When the EDTA-T gels were analyzed, the non-parametric Kruskall Wallis test also showed that there was a statistically significant difference between the gels tested regarding smear layer scores $(\mathrm{p}<0.0001)$. All the EDTA-T gels exhibited a lower smear layer score when compared to the control group ( $p<0.001$ ), but no difference could be found between the different concentrations of EDTA-T gels tested ( $p>0.05$ ).

When considering the application time as an independent variable, the 3-minute application time led to a higher smear layer removal than the other two application times tested $(\mathrm{p}<0.05)$ (data not shown). The non-parametric Mann-Whitney test demonstrated that, when the smear layer removal scores between groups II (EDTA) and III (EDTA with Texapon) were tested for each concentration, $5 \%$ and 10\% EDTA gels had statistically significant lower smear layer scores when compared to 5\% $(<0.0001)$ and 10\% EDTA-T (0.0237) gels, with no difference when the two gel formulations were tested for the other concentrations (Table 1).

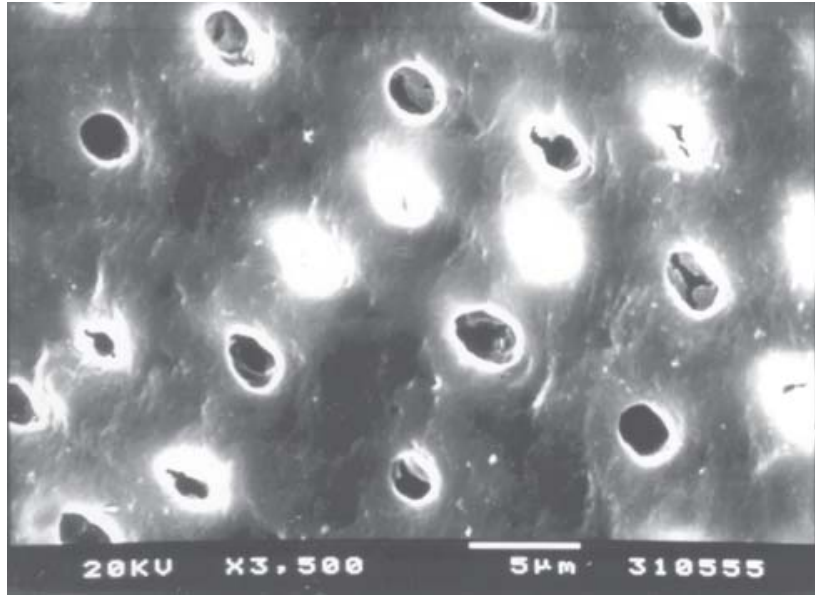

FIGURE 3- SEM of a 10\% EDTA group specimen showing a root surface without smear layer with the dentinal tubules completely open, but with some evidence of smear layer in the dentinal tubules entrance (score 2). (3500x magnification; bar $=5 \mu \mathrm{m}$ )

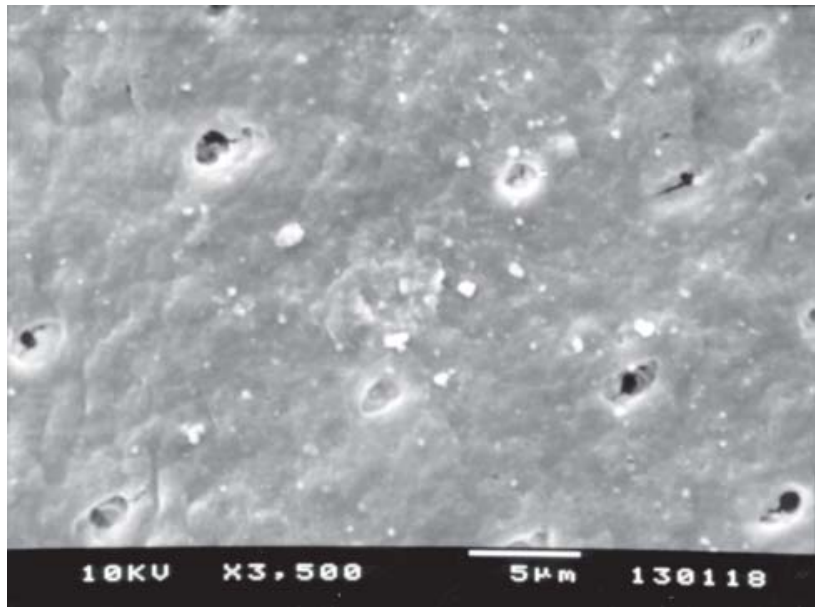

FIGURE 4- SEM of a $24 \%$ EDTA group specimen showing a root surface without smear layer with the dentinal tubules partially open (score 3 ). (3500x magnification; bar $=5 \mu \mathrm{m}$ )

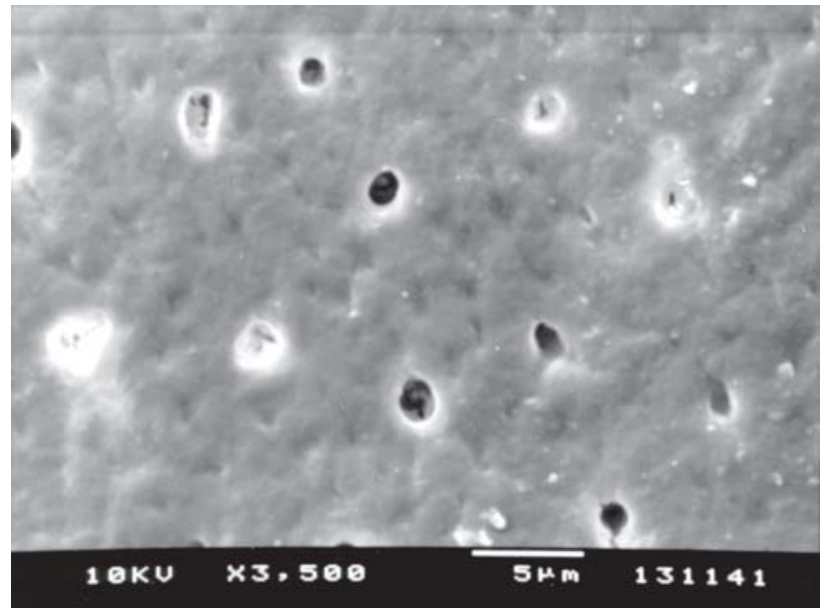

FIGURE 5- SEM of a 24\% EDTA-T group specimen showing a root surface without smear layer, with the dentinal tubules partially open (score 3). (3500x magnification; bar $=5 \mu \mathrm{m}$ ) 


\section{DISCUSSION}

Since the presence of endotoxins and the possibility of bacterial invasion in periodontally diseased cementum and dentin have been demonstrated ${ }^{1,2,11,12,17}$, the use of chemical agents such as citric acid has been suggested as an important step during periodontal new attachment procedures (recently termed periodontal regenerative procedures). Smear layer removal by the use of root surface conditioning agents could favor a new connective tissue attachment with new cementum formation after regenerative procedures, although in vivo studies have failed to demonstrate significant clinical differences between conditioned root surfaces and controls, in both surgical and non-surgical periodontal therapies ${ }^{9,10}$. Root surface conditioning, by exposure of collagen fibers of the dentin extracellular matrix ${ }^{1-}$ 2, may favor fibrin deposition and consequently clot stabilization in the earliest phase of periodontal healing ${ }^{3}$, increasing the retention and contact of substances actually used during regenerative procedures, such as enamel matrix derivative proteins which could act as growth factor during the periodontal healing process ${ }^{13}$. In this study, the specimens treated by scaling and root planing followed by saline solution application (Group I) demonstrated an irregular smear layer formation along the root surface, in accordance to several previous studies ${ }^{1,2,11}$ (Figure 1). On the other hand, the use of EDTA gel with or without a detergent (Texapon) after scaling and root planing procedures resulted in effective smear layer removal with dentinal tubules exposure in many specimens in SEM photomicrographs. These findings are in accordance to several studies where the use of EDTA led to a complete smear layer removal of the root surface ${ }^{5,6,8}$.

Many substances have been proposed for root surface conditioning after scaling and root planing. Recently EDTA, which has a neutral $\mathrm{pH}$, has maintained more vital periodontal cells adjacent to the etched surface when compared to low-pH agents, such as citric acid. In the present study, a detergent named Texapon was added to the EDTA gel formulation (EDTA-T) in order to decrease the surface tension and to facilitate the spreading over the root surface. The effects of the association between EDTA and Texapon on smear layer removal and also on dentinal tubules exposition were analyzed. The SEM analysis showed that EDTA-T gel application resulted in a similar smear layer removal and dentinal tubules opening compared to the group where the specimens received EDTA gel application without Texapon (EDTA). This demonstrates that the addition of Texapon detergent in the EDTA gel formulation did not improve the in vitro results seen for the EDTA gel group. On the other hand, Okte \& Bal using 2\% sodium lauryl sulfate and $0.1 \%$ cetylpyridinium chloride on the root surface for a longer application time (5 minutes), observed that the treated root surface presented partially demineralized aspect, with dentinal tubules and collagen fibers exposure ${ }^{20}$.

In this study, the EDTA gel (without detergent) in the concentrations of $5 \%$ and $10 \%$ resulted in statistically significantly lower smear layer scores than in higher concentrations. This surprising result could be explained by the fact that the EDTA gel formulation exhibited a higher viscosity for the higher concentrations which could have hindered the EDTA gel spreading over the mechanically treated root surface. An effective contact of the EDTA gel molecules to the root surface probably did not occur, and consequently fewer calcium ions were removed of the cementum or dentin surface, leading to an incomplete smear layer removal. Therefore, EDTA gel formulation in lower concentrations such as $5 \%$ or $10 \%$ resulted in an easily

TABLE 1- Comparison of smear layer removal scores between experimental groups, in each tested concentration $(n=20)$

\begin{tabular}{|c|c|c|c|c|}
\hline \multirow[t]{2}{*}{ Concentration } & \multirow[t]{2}{*}{ Groups } & \multicolumn{2}{|c|}{ Scores } & \multirow[t]{2}{*}{$P^{* *}$} \\
\hline & & Median & Rank Sum & \\
\hline \multirow[t]{2}{*}{$5 \%$} & EDTA & 1.0 & 258 & 0.0001 \\
\hline & EDTA-T* & 3.0 & 562 & \\
\hline \multirow[t]{2}{*}{$10 \%$} & EDTA & 2.0 & 326.5 & 0.0237 \\
\hline & EDTA-T & 3.0 & 493.5 & \\
\hline \multirow[t]{2}{*}{$15 \%$} & EDTA & 3.0 & 446.5 & 0.3271 \\
\hline & EDTA-T & 2.0 & 373.5 & \\
\hline \multirow[t]{2}{*}{$20 \%$} & EDTA & 3.0 & 419 & 0.8169 \\
\hline & EDTA-T & 3.0 & 401 & \\
\hline \multirow[t]{2}{*}{$24 \%$} & EDTA & 3.0 & 451.5 & 0.2633 \\
\hline & EDTA-T & 3.0 & 368.5 & \\
\hline
\end{tabular}

\footnotetext{
* EDTA plus Texapon

** refers to the Mann-Whitney test.
} 
spreading over the root surface, which may have favored the smear layer removal.

Regarding the application times tested, the EDTA gel application for 3 minutes resulted in greater smear layer removal than in the subgroups where the gel was applied for 1 or 2 minutes. Thus, the application time could influence the effectiveness of smear layer removal and dentinal tubules opening by the EDTA gel formulations. These findings corroborate several studies that have analyzed the influence of application time of this root surface conditioning agent $t^{4,7}$.

\section{CONCLUSION}

According to the results found in this study, it is possible to conclude that EDTA gel effectively removed smear layer of instrumented root surface, and that the addition of a detergent (Texapon) in its formulation did not improve the results commonly found with the use of the EDTA gel without detergent. Further studies are necessary to establish the in vivo importance of EDTA gel application as an additional step during periodontal therapy, especially in regenerative procedures, as a way to provide a biologically acceptable environment that could favor connective tissue cell colonization of previously diseased root surfaces.

\section{ACKNOWLEDGEMENT}

This work was supported by grants (520658/98-1) from Conselho Nacional de Desenvolvimento Científico e Tecnológico (CNPq), Brazil.

\section{REFERENCES}

1- Adriaens PA, Loesche WJ, De Boever JA. Bacterial invasion in root cementum and radicular dentin of periodontally diseased teeth in humans. J Periodontol. 1988;59:222-30.

2- Aleo JJ, De Renzis FA, Farber PA, Varboncoeur AP. The presence and biologic activity of cementum bound endotoxin. J Periodontol. 1974;45:672-75.

3- Baker PJ, Rotch HA, Trombelli I, Wikesjo UME. An in vitro screening model to evaluate root conditioning protocols for periodontal regenerative procedures. J Periodontol. 2000;71:1139-43.

4- Bergenholtz A, Babay N. Scanning electron microscopy of the root surface texture of extracted periodontally diseased teeth following various etching and chelating regimens. Int J Periodontics Restorative Dent. 1998;18:171-9.

5- Blomlöf J, Blomlöf LB, Lindskog SF. Smear removal and collagen exposure after non-surgical root planing followed by etching with an EDTA gel preparation. J Periodontol. 1996;67:841-5.

6- Blomlöf J, Jansson L, Blomlöf L, Lindskog S. Etching at neutral pH promotes periodontal healing. J Clin Periodontol. 1996;23:50-5.

7- Blomlöf J, Lindskog,S. Root surface texture and early cell and tissue colonization after different etching modalities. Eur J Oral Sci. 1995;103:17-24.
8- Blomlöf JPS, Blomlöf LB, Lindskog SF. Smear layer formed by different root planing modalities and its removal by an ethylenediaminetetraacetic acid gel preparation. Int J Periodont Restorative Dent. 1997;17:243-9.

9- Blomlöf L, Bergman E, Forsgardh A, et al. A clinical study of root surface conditioning with an EDTA gel. II. Non surgical periodontal treatment. Int J Periodontics Restorative Dent. 2000;20:561-5.

10- Blomlöf L, Jonsson B, Blomlöf J, Lindskog S. A clinical study of root surface conditioning with and EDTA gel. II. Surgical periodontal treatment. Int J Periodontics Restorative Dent. 2000;20:567-73.

11- Cogen RB, Garrison DC, Weatheford TW. Effect of various root surface treatments on the viability and attachment of human gingival fibroblasts. J Periodontol. 1983;54:277-82.

12- Coldiron NB, Yukna RA, Weir J, Cauldill RF. A quantitative study of cementum removal with hand curettes. J Periodontol. 1990;61:2939 .

13- Froum S, Lemler J, Horowitz R, Davidison B. The use of enamel matriz derivate in treatment of periodontal osseous defects: a clinical decision tree based on biologic principles of regeneration. Int $\mathrm{J}$ Periodontics Retorative Dent. 2001;21:437-49.

14- Karring T, Nyman S, Gottlow J, Laurell L. Development of the biological concept of guided tissue regeneration. Animal and human studies. Periodontol 2000. 1993;1:26-35.

15- Kerns DG, Scheidt MJ, Pashley DH, Horner JA, Strong SL, Van Dyke TE. Dentinal tubule occlusion and root hypersensitivity. J Periodontol. 1991;62:421-8.

16- Lafferty TA, Gher ME, Gray JL. Comparative SEM study on the effect of acid etching with tetracycline HCL or citric acid on instrumented periodontally-involved human root surfaces. J Periodontol. 1993;64:689-93.

17- Larjava H, Salomen J, Hakkinem L, Narhi T. Effect of citric acid treatment on the migration of epithelium on root surfaces in vitro. J Periodontol. 1988;1:95-9.

18- Lindskog S, Blomlöf J, Blomlöf L. Root surface conditioning. In: Hugoson A, Lundgren D, Lindgren B. Guided Periodontal Tissue Regeneration. Stockolm:Gothia, 1995:127-38.

19- Mader CL, Baugartner JC, Peters DD. Scanning electron microscopic investigation of the smeared layer on root canal walls. J Endod. 1984;10:477-85

20- Ökte E, Bal B. Topography of periodontally involved human root surfaces after different chemical treatment modalities: An in vivo scanning electron microscopic study. J Oral Sci. 2000;42:139-46.

21- Polson AM, Frederic GT, Ladenheim S, Hanes PJ. The production of a root surface smear layer by instrumentation and its removal by citric acid. J Periodontol. 1975;46:646-55.

22- Polson AM, Ladenheim S, Hanes PJ. Cell and fiber attachment to demineralized dentin from periodontitis affected root surfaces. J Periodontol. 1986;57:235-46.

23- Register AA. Bone and cementum induction by dentin, demineralized in situ. J Periodontol. 1973;44:235-46.

24- Stahl SS. Repair potential of the soft tissue-root interface. J Periodontol. 1977;48:545-52.

25- Trombelli L, Scabbia A, Zangari F, Griselli A, Wikesjo UME, Calura G. Effect of tetracycline on periodontally-affected human root surfaces. J Periodontol. 1995;66:685-91. 